\title{
French school and World War First: neurological consequences of a frightening time
}

\author{
Escola neurológica francesa e Primeira Guerra Mundial: desdobramentos neurológicos de \\ uma época assustadora
}

Marleide da Mota Gomes

\begin{abstract}
Some aspects of a dark period in the history of the modern neurology, that of the World War I (WWI), are here remembered, mainly by the neurological French School participation. Some personalities and their works related to the WWI are presented such as Joseph Babinski, Jules Froment, Clovis Vincent, Jules Joseph Dejerine, Augusta Déjérine-Klumpke, Jules Tinel, Pierre Marie, Achille Alexandre Souques, Charles Foix, and Georges Guillain.
\end{abstract}

Keywords: neurology, World War I, hysteria, camptocormie, peripheral neuropathy.

\section{RESUMO}

Alguns aspectos de um período negro da história da neurologia, a da Primeira Guerra Mundial, são aqui lembrados, principalmente pela participação da escola neurológica francesa. Algumas personalidades e suas obras relacionadas à Primeira Guerra Mundial são apresentadas, como Joseph Babinski, Jules Froment, Clovis Vincent, Jules Joseph Dejerine, Augusta Dejerine-Klumpke, Jules Tinel, Pierre Marie, Achille Alexandre Souques, Charles Foix, and Georges Guillain.

Palavras-chave: neurologia, Primeira Guerra Mundial, histeria, camptocormia, neuropatia periférica.

The innovative and elegant Belle Époque began after one war, the Franco-Prussian (July 19, 1870-May 10, 1871), and it ended in a new one, the World War I (WWI) (July 28, 1914-November 11, 1918). At the beginning, this last war involved the Triple Entente of the United Kingdom, France and the Russian Empire against the Central Powers of Germany and Austria-Hungary. In between the mentioned wars, the French neurology flourished together with the Belle Époque and when the WWI began, it was still in its zenith ${ }^{1}$. At this time, pressed by necessity, they were developed techniques for dealing with millions of soldiers who suffered horrific injuries. While many of the medical advances during this conflict dealt with mutilations, there were also psychological or neurological wounds. Consequently, the French illustrious neurologists had to face this first large-scale war never experienced before. This paper raises some neurological issues related to this major upheaval, and the French neurologists participation.

\section{FRENCH NEUROLOGISTS IN THE WORLD WAR I}

The leading neurologist linked to war at this time was Joseph Babinski (1857-1932). Babinski directed two centers for wounded soldiers at La Pitié and at the Lycée Buffon ${ }^{1}$. Babinski was involved soon with the care of the wounded soldiers, and in 1915 with or without Jules Froment (1878-1946), he published eighteen papers on nervous disorders due to traumatic nerve lesions ${ }^{1}$. At these places, the wounded soldiers under care suffered from several disorders, and those considered psychic varies from 1.4 to 7.1 from 1915-1917². In 1917, Babinski and Froment (the latter, now most remembered by his "signe de journal"), published a book about Hysteria, pithiatism, and reflex neurological disorders ${ }^{2}$ (Figure 1). This "pithiatism" was caused by psychological trauma that often expressed itself as extreme anxiety and seemingly neurological symptoms. This book deals with hysterical symptoms, primarily psychological, and physiopathic disorders, vasomotor - secretive 
- trophic, of reflex nature. Moreover, the authors had to distinguish between patients with nervous organic lesions, from those with "pithiatism" and those simulating an illness to avoid being sent to the battleground. The neurological semiology and several signs and maneuvers are carefully demonstrated for the differentiation between organic from psychogenic palsies. Babinski's pupil Clovis Vincent (1879-1947) in the years of 1915-1916, developed a persuasive method to push the soldier to the front lines, called torpillage at first by those submitted to this technique ${ }^{3}$.

An older Babinski's colleague, the head of the Salpêtrière from 1911 until February 1917, was Jules Joseph Déjérine (1849-1917). Déjérine died from nephritis and its consequences when he was in charge of a neurological war hospital since 1914 4 . His wife, Augusta Dejerine-Klumpke (1859-1927) also worked at this time at the Salpêtrière Hospital (300 beds) and soon after at the Invalides military hospital in Paris. Dejerine-Klumpke was also a pioneer in France, with the help of her daughter - Dr Y Sorrel-Déjérine (1891 \pm 1986$)$ - during the WWI and subsequent following years, in the treatment and rehabilitation (medical and vocational) of the large number of soldiers afflicted by wounds of the nervous system ${ }^{4}$. Another branch of Jules Déjérine School reaches Jules Tinel (1879-1952) who described the "fourmillement signal" or "Tinel sign" in lesioned nerves ${ }^{5,6,7}$. Tinel published it in the same year that Paul Hoffmann (1884-1962), at the other side of the front, defined equivalent signal in two publications (1915). Tinel mentioned the pressure applied to the injuried nerve, and Hoffman mentioned it but also that a light percussion was a better method to elicit the signal. Tinel published likewise a book Nerve wounds ${ }^{6}$ (1916) (Figure 2), based on his experience in the war, because he was assigned to an infantry regiment (1914), and in the following year (1915) he founded a regional neurological center at the front $t^{5}$.

Pierre Marie (1853-1940) succeeded Déjérine in the Salpêtrière chair few weeks later the predecessor's death. He published various works dedicated to the neurological sequels due to $\mathrm{WWI}^{7,8}$, in collaboration with Charles Foix (1882-1927), mainly about aphasias ${ }^{8}$, and Henry Meige (1866-1940), mainly about peripheral neuropathies, among others. During the war period, Marie dealt with previously health and young subjects with gun-shot and shrapnel injuries with resulting aphasiogenic lesion. Previously, Marie had a holistic and cognitive ideas on aphasia what was criticized by his contemporaries, especially by Déjérine. This war experience, redirected Marie's previous conceptions to one that admitted the aphasia localizationism, as can be seen in "Speech disorders due to wound caused by war projectile". Regarding one of his collaborators, Charles Foix (1882-1927), ex Pierre Marie's resident, the famous stroke researcher, served during WWI in the neurological center of Salonika in Greece'. Achilles Souques Alexander (1860-1944) was one of the last Charcot residents and worked with Marie. Souques and Ms.

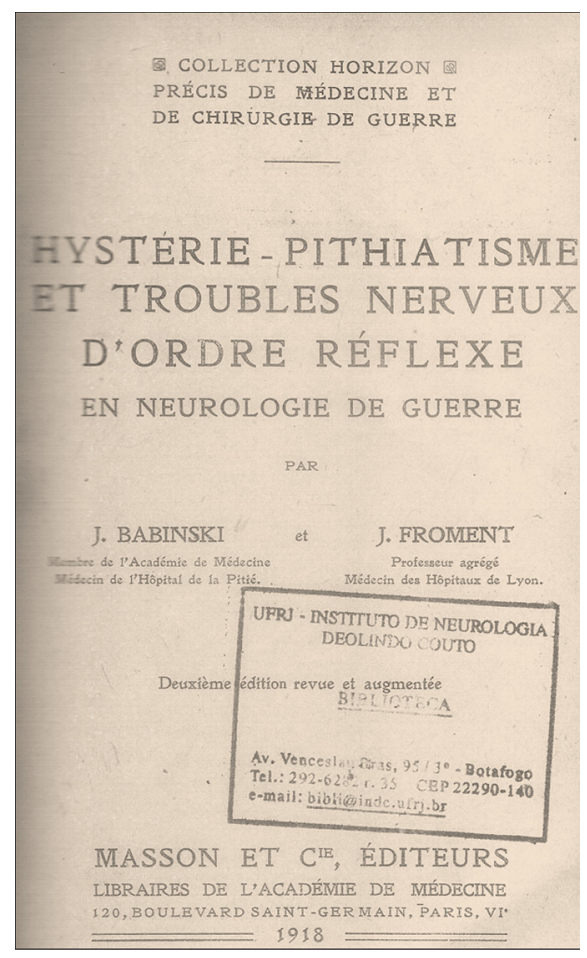

Figure 1. The book Pithiatism-hysteria and nervous disorders of reflex quality in war neurology by Babinski and Froment ${ }^{2}$. In this book, several signs differentiate weakness due to structural lesions of the central nervous system from weakness caused by hysteria, besides phenomena entitled physiopathic. This last one was not considered neither hysteria nor any other psychopathic state that can produce it, but it would be a disorder of the nervous system which could not be detected by the methods at the time.

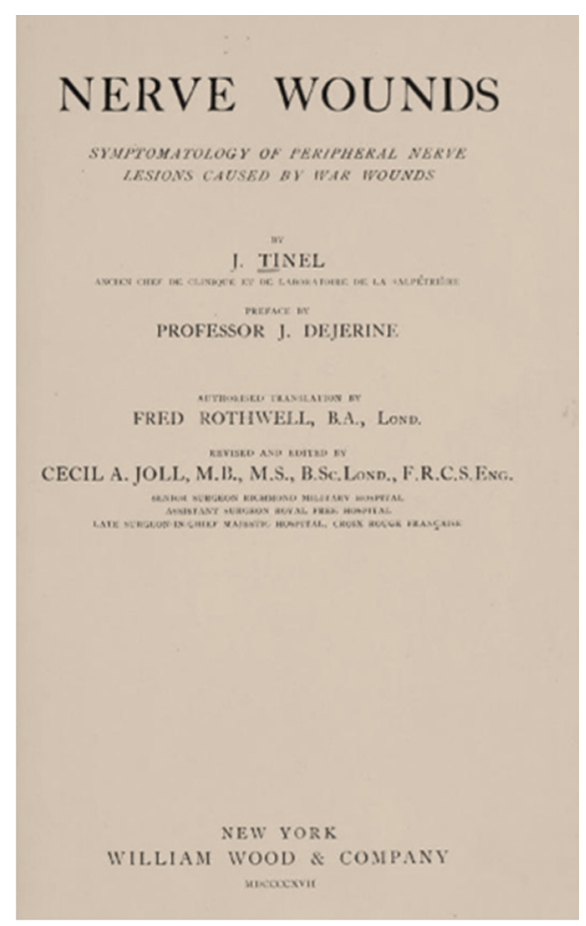

Figure 2. The book Nerves wounds... caused by war wounds by Tinel with a preface by Déjérine (four parts - general survey, upper limb, lower limb, conclusions - and 26 chapters), richly illustrated and published in 1916. Here presented an English version, $1918^{6}$. 
Rosanoff-Saloff studied the camptormie, or bent spine syndrome $^{9}$. She refers to an article in la Nouvelle Iconographie de la Salpétrière that this first term was given by Souques (1915). She also mentions that the war has provided many examples of the trunk bends, and she published 16 observations of camptocormique soldiers taken into Souques's Service, with many supporting photographs. According to Souques who published in the same Icnographie volume, the treatment of choice to these soldiers who were suffering from functional camptocormie would be the same advocated by Clovis Vincent, but instead of galvanic current, Souques proposed faradaic one (Figure 3).

Following Pierre Marie, Georges Guillain (1876-1961) was appointed as Salpêtrière chairman, a few years later the end of the WWI (1923-1947). He with Jean Alexandre Barré (1880-1967), ex Babinski's resident, and André Strohl (1887-1977) worked together in the French army. They
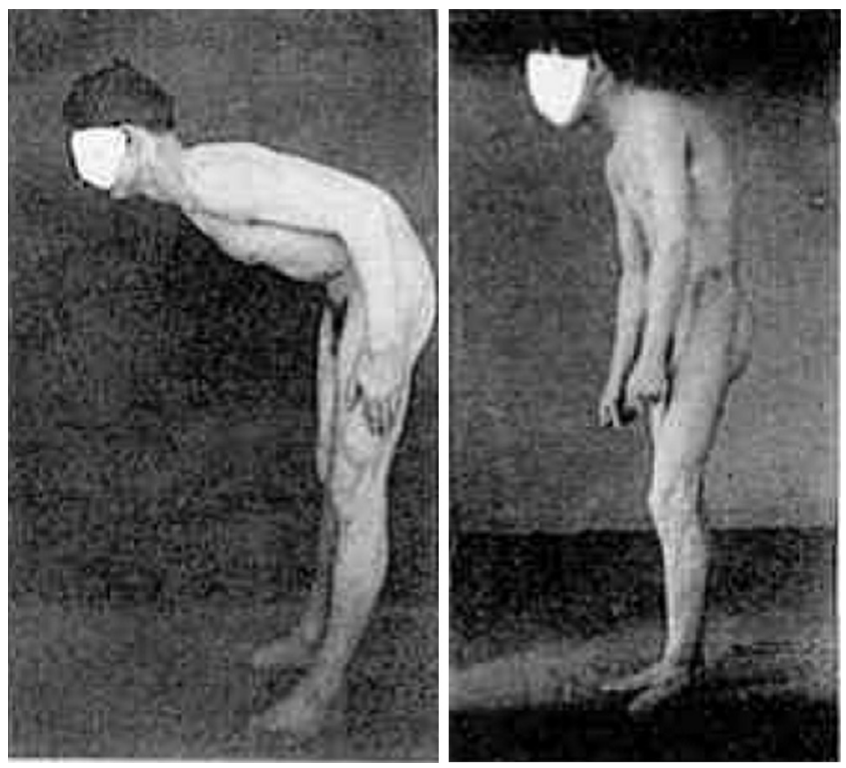

Figure 3. Camptocormie before and after faradaic treatment by Souques in the paper Traitement de la camptocormie par l'électrothérapie persuasive? witnessed (1916) two similar cases of soldiers who had partial paralysis with significant impairment of reflexes, which would recover spontaneously. with motor weakness, areflexia, and albuminocytological dissociation in the cerebrospinal fluid. Strohl performed the electrophysiological tests, and in 1920 the first two published a book about their experiences in the war neurology (Figure 4).

In conclusion, during the WWI some important and lasting contributions to clinical neurology were described especially those concerning differentiations between organic and functional hemiplegia, war-related peripheral nerve disorders, e.g. Such studies required knowledgeable neurologists as those from the French neurological School who made the most out of their opportunities to systematically assess and care a large number of injured soldiers in a short period of time.
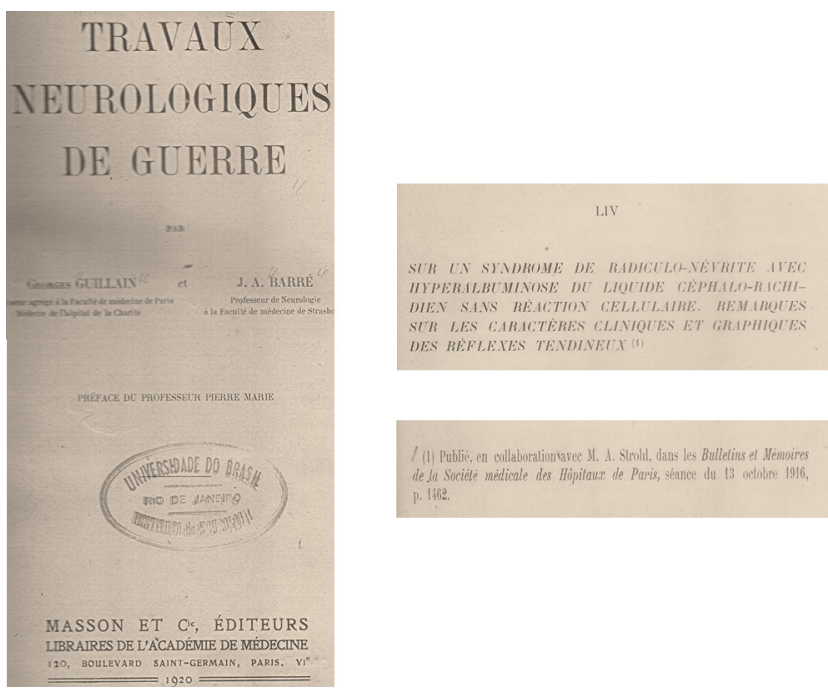

Figure 4. The book Neurological war work ${ }^{10}$ by Guillain and Barré with a preface by Pierre Marie and six chapters (Nervous semiology, Wounds of the Brain, Wounds of the Spinal Cord, Concussion Without External Wounds Resulting from the Explosion of Shells, Pathology of the Cranial and Spinal Nerves, Varia). Included (right side) a 1916 publication regarding the Guillain-Barré-Strohl syndrome.

\section{References}

1. Philippon J, Poirier J. Joseph Babinski: a biography. York: Oxford University Press; 2008

2. Babinski JFF, Froment J. Hystérie-pithiatisme et troubles nerveux d'ordre réflexe en neurologie de guerre. 2ème éd. Paris: Masson; 1918.

3. Vincent C. Le traitement des phénomènes hystériques par la "rééducation intensive. Arch Electr Médicale. 1916;411:405-416.

4. Schurch B, Dollfus P. The 'Dejerines': an historical review and homage to two pioneers in the field of neurology and their contribution to the understanding of spinal cord pathology. Spinal Cord. 1998;36(2):78-86.

5. Spaans F. The Hoffmann-Tinel sign. In: Koehler PJ, Bruyn GW, Pearce JMS, editors. Neurological eponyms. Oxford: Oxford University Press; 2000:136-142.
6. Tinel J. Nerve wounds: symptomatology of peripheral nerve lesions caused by war wounds. New York: William Wood; 1917.

7. Marie P, Souques A, Babinski J, Thomas A, Lavastine L, Français H et al. Centres neurologiques de guerre: neurologie de guerre. Rev Neurologique 1917;2:331-460.

8. Marie P, Foix C. Les aphasies de guerre. Rev Neurol 1917;1 (2-3):53-87.

9. Rosanoff-Saloff. Considérations générales sur la camptocormie. Nouv Iconographie Salpétrière. 1916-1917;28:28-33.

10. Souques A, Mégevand J, Naiditch, Rathaus. Traitement de la camptocormie par l'électrothérapie persuasive. Nouv Iconographie Salpétrière. 1916-1917;28:420-37.

11. Guillain G, Barre JA. Travaux neurologiques de guerre. Paris: Masson; 1920. 